\title{
The Pseudomonas aeruginosa acsA gene, encoding an acetyl-CoA synthetase, is essential for growth on ethanol
}

\author{
Utta Kretzschmar, Max Schobert and Helmut Görisch
}

Fachgebiet Technische Biochemie, Institut für Biotechnologie der Technischen Universität Berlin, Seestraße 13, D-13353 Berlin, Germany
Author for correspondence: Helmut Görisch. Tel: +4930314 27582. Fax: +49 3031427581. e-mail: Goerisch@lb.TU-Berlin.De

\begin{abstract}
Pseudomonas aeruginosa ATCC 17933 uses a pyrroloquinoline quinonedependent ethanol oxidation system. Two mutants of $P$. aeruginosa, unable to grow on ethanol and showing no acetyl-CoA synthetase (ACS) activity under standard test conditions, were complemented by cosmid pTB3018. Subcloning led to the isolation of a gene which encodes a protein with high similarity to acetyl-CoA synthetases. Interruption of the putative acsA gene by a kanamycin-resistance cassette resulted in a mutant also unable to grow on ethanol and with very low residual acetyl-CoA-forming activity. Complementation by the wild-type allele of the acsA gene restored growth and led to the expression of ACS activity in excess of that of wild-type cells. In wild-type $P$. aeruginosa, ACS activity was induced upon growth on ethanol, 2,3butanediol, malonate and acetate. The wild-type and mutants defective in ACS activity showed an active acetate kinase (ACK) under the growth conditions used; however, phosphotransacetylase (PTA) could not be detected. The data indicate that $P$. aeruginosa requires active acs $A$ gene product for growth on ethanol.
\end{abstract}

Keywords: ethanol oxidation, acetate metabolism, acetate kinase, phosphotransacetylase, Pseudomonas aeruginosa

\section{INTRODUCTION}

Pseudomonas aeruginosa ATCC 17933 grows aerobically with ethanol as its sole source of carbon and energy. Recently, we identified an exaABC gene cluster, encoding components of the ethanol oxidizing system. The three genes encode an unusual quinoprotein ethanol dehydrogenase $\left(\mathrm{QEDH}\right.$, exaA), an $\mathrm{NAD}^{+}$-dependent acetaldehyde dehydrogenase $($ exaC) and a cytochrome $c_{550}$ (exaB) (Fig. 1) (Diehl et al., 1998; Reichmann \& Görisch, 1993; Schobert \& Görisch, 1999).

Some pseudomonads use an $\mathrm{NAD}^{+}$- and CoA-dependent acylating acetaldehyde dehydrogenase, EC 1.2.1.10, for activation of acetate (Eaton, 1996; Powlowski et al., 1993). Other organisms oxidize acetaldehyde to acetate by a CoA-independent dehydrogenase. The acetate in turn can be converted to acetyl-CoA by two different routes (Fig. 1). Most organisms synthesize acetyl-CoA

Abbreviations: ACK, acetate kinase; ACS, acetyl-CoA synthetase; PQQ, pyrroloquinoline quinone; PTA, phosphotransacetylase; QEDH, quinoprotein ethanol dehydrogenase. using either the acetyl-CoA synthetase (ACS) reaction or the acetate kinase (ACK) / phosphotransacetylase (PTA) sequence. For instance, Pseudomonas PAO (Champine \& Goodwin, 1991) and Methanosarcina thermophila (Aceti \& Ferry, 1988) use ACK (EC 2.7.2.1) and PTA (EC 2.3.1.8) to form acetyl-CoA. In contrast, bacteria like Pseudomonas AM1 (Taylor \& Anthony, 1976), Methanobacterium thermoautotrophicum (Oberlies et al., 1980), Methanothrix soehngenii (Jetten et al., 1989; Eggen et al., 1991) and Alcaligenes eutrophus (Steinbüchel et al., 1987; Priefert \& Steinbüchel, 1992) use ACS (EC 6.2.1.1). Some bacteria, such as Escherichia coli (Brown et al., 1977; Kumari et al., 1995; Chang et al., 1999) and Bacillus subtilis (Grundy et al., 1993), possess both routes for interconverting acetate and acetyl-CoA.

Recently, we isolated mutants of $P$. aeruginos a unable to grow on ethanol. Mutants MS1 and MS8 have a defect in a structural or regulatory gene of either the electron transport chain specific for the quinoprotein ethanol oxidation system or the metabolism of acetaldehyde and acetate (Schobert \& Görisch, 1999). The present communication describes the identification of the gene acs $A$, 


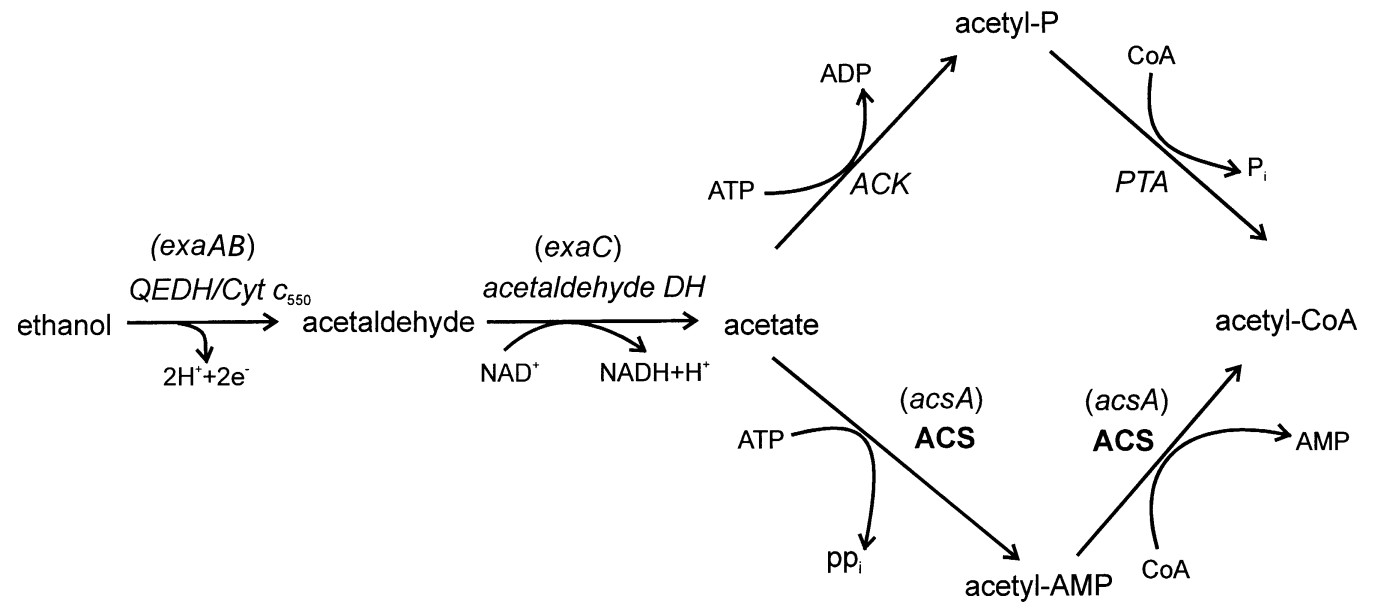

Fig. 1. Genes and gene products of the exa gene cluster in $P$. aeruginosa and the enzymes studied.

which encodes ACS, essential in $P$. aeruginosa ATCC 17933 for growth on ethanol.

\section{METHODS}

Bacterial strains and culture conditions. Bacterial strains and plasmids are listed in Table 1. P. aeruginosa mutants MS1 and MS8 contained an active QEDH and secreted pyrroloquinoline quinone (PQQ) in the culture supernatants, but were unable to grow on ethanol. E. coli was grown at $37^{\circ} \mathrm{C}$ in LB medium. P. aeruginosa ATCC 17933 and mutants were cultivated at $37^{\circ} \mathrm{C}$ in LB or in minimal media (Rupp \& Görisch, 1988) containing different carbon sources: $86 \mathrm{mM}$ $(0.5 \%, \mathrm{v} / \mathrm{v})$ ethanol; $40 \mathrm{mM}$ succinate; $25 \mathrm{mM}$ glucose; $20 \mathrm{mM}$ acetate; $22 \mathrm{mM}$ 2,3-butanediol; $7 \mathrm{mM}$ malonate. When appropriate, $50 \mu \mathrm{g}$ kanamycin $\mathrm{ml}^{-1}, 20 \mu \mathrm{g}$ tetracycline $\mathrm{ml}^{-1}$ or $100 \mu \mathrm{g}$ carbenicillin $\mathrm{ml}^{-1}$ was added.

Recombinant DNA work and genetic techniques. Standard protocols were followed for plasmid isolation, restriction enzyme analyses, ligation, transformation (by electroporation), gel electrophoresis and other DNA manipulations (Sambrook et al., 1989). For DNA sequencing, a sequenase kit and ${ }^{35}$ S-labelled ATP (Amersham) were used.

Triparental matings between E. coli JM109 and P. aeruginosa mutants were carried out by mixing aliquots of overnight cultures on LB agar. E. coli HB101 carrying pRK2013 was used as helper strain. After $6 \mathrm{~h}$ at $37^{\circ} \mathrm{C}$, cells were resuspended and spread on both succinate and selective ethanol minimal medium.

For PCR amplification of the acs $A$ gene, the $4.8 \mathrm{~kb}$ fragment of pTB4102 was used as template. Pfu DNA polymerase (Stratagene) was used according to the instructions of the manufacturer. As primers the oligonucleotide 5'-AGT GGA TCC GTT GAT CTC GCT GTG G-3' complementary to a sequence 205 bp upstream of the start codon and the oligonucleotide 5'-AGT GGA TCC GAA GTG TTA CCG CGC C$3^{\prime} 109 \mathrm{bp}$ downstream of the stop codon TGA of ORF2 were used.

Construction of an acsA:: $\mathbf{K m}^{\mathbf{r}}$ mutant. A pUC19 derivative, pTB4108, containing a $5.8 \mathrm{~kb}$ fragment from pTB4107 with the kanamycin-resistance gene of transposon $\operatorname{Tn} 5$ in the acs $A$ gene, was used to transform $P$. aeruginosa by electroporation
(Smith \& Iglewski, 1989). Potential site-directed doublecrossover mutants with a $\mathrm{Km}^{\mathrm{r}}$ phenotype were selected for loss of ampicillin resistance.

Induction of enzyme activity. Strains were grown in minimal medium with succinate as carbon source. At an $\mathrm{OD}_{620}$ of $0 \cdot 8$, cells were collected by centrifugation, washed twice and resuspended in twice the amount of minimal medium with $0.5 \%(\mathrm{v} / \mathrm{v})$ ethanol to induce the ethanol oxidation system. After incubation for $5 \mathrm{~h}$ at $37^{\circ} \mathrm{C}$, cells were harvested by centrifugation.

Preparation of cell-free extracts. Bacteria were grown to lateexponential phase, harvested, and washed twice with $20 \mathrm{mM}$ potassium phosphate buffer $(\mathrm{pH} 7 \cdot 0)$. The wet cell paste (1-2 g) was resuspended in $10 \mathrm{ml} 10 \mathrm{mM}$ Tris/ $\mathrm{HCl}$ buffer ( $\mathrm{pH} 7 \cdot 9$ ). After cell disruption by sonication, the cell homogenate was centrifuged for $30 \mathrm{~min}$ at $6000 \mathrm{~g}$. The supernatant contained $1.5-4 \mathrm{mg}$ protein $\mathrm{ml}^{-1}$ and was stored at $-80{ }^{\circ} \mathrm{C}$ as cell-free extract. Under these conditions, ACS and ACK activities were stable for several days. For the detection of low enzyme activity, cell-free extracts with about $10 \mathrm{mg}$ protein $\mathrm{ml}^{-1}$ were prepared.

Enzyme assays. Enzyme activities were determined with cellfree extracts. For standard tests, $0.5-1.3 \mathrm{mg}$ protein was used in a total test volume of $1 \mathrm{ml}$. For the determination of low enzyme activity, about $6 \mathrm{mg}$ protein was used per test. ACS activity was assayed in $0 \cdot 1 \mathrm{M}$ Tris/ $\mathrm{HCl}$ buffer, $\mathrm{pH} 8 \cdot 5$, by monitoring the formation of acetyl-CoA from acetate, CoA and ATP (Jones \& Lipman, 1955; Berg, 1962). ACK activity was determined by measuring the formation of acetyl-P from acetate and ATP (Aceti \& Ferry, 1988; Eggen et al., 1991). Acetyl-CoA and acetyl-P were determined as the trivalent iron complex of acetylhydroxamate at $540 \mathrm{~nm}$. Enzyme activities below $0.025 \mathrm{U}$ per assay mixture cannot be detected. One unit $(\mathrm{U})$ is defined as $1 \mu \mathrm{mol}$ product formed in $20 \mathrm{~min}$. Using the same cell extract, standard deviations of the enzymic test were calculated as $\pm 9 \%$ for ACS and $\pm 3 \%$ for ACK activity. PTA activity was determined with acetyl phosphate and CoA as substrates. Formation of acetyl-CoA was followed by the absorption increase of the thioester linkage at $233 \mathrm{~nm}$ (Thompson \& Chen, 1990). Protein concentrations were determined using the method of Groves et al. (1968).

Internet tools. The following internet services were used: BLAST for DNA or protein database searches (Altschul et al., 
Table 1. Strains and plasmids used in this study

\begin{tabular}{|c|c|c|}
\hline Strain or plasmid & Relevant properties* & Reference \\
\hline \multicolumn{3}{|l|}{ Strains } \\
\hline \multicolumn{3}{|l|}{ P. aeruginosa } \\
\hline ATCC 17933 & Wild-type & Cetin et al. (1965) \\
\hline MS1, MS8 & ATCC 17933 derivative, mutant class I & Schobert \& Görisch (1999) \\
\hline UK1 & ATCC 17933 derivative, acs $A:: \mathrm{Km}^{\mathrm{r}}$ & This study \\
\hline \multicolumn{3}{|c|}{ (1) } \\
\hline JM109 & 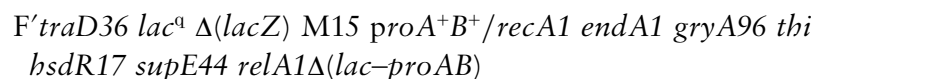 & Yanisch-Perron et al. (1985) \\
\hline HB101 & $\begin{array}{l}\text { supE44 hsdS20 }\left(\mathrm{r}_{\mathrm{B}}^{-} \mathrm{m}_{\mathrm{B}}^{-}\right) \text {recA13 ara-14 proA2 lacY1 galK2 rpsL20 } \\
\text { xyl-5 mtl-1 }\end{array}$ & Boyer \& Roulland-Dussoix (1969) \\
\hline $\mathrm{DH} 5 \alpha$ & supE44AlacU169( $\phi 80$ lacZ $\Delta \mathrm{M} 15)$ hsdR17 recA1 gyrA96 thi-1 relA1 & Hanahan (1983) \\
\hline \multicolumn{3}{|l|}{ Plasmids } \\
\hline pLAFR3 & $T c^{r} ;$ broad-host-range cosmid & Staskawicz et al. (1987) \\
\hline pRK2013 & $\mathrm{Km}^{\mathrm{r}}$; helper plasmid for triparental mating & Figurski \& Helinski (1979) \\
\hline pSUP1021 & $\mathrm{Tc}^{\mathrm{r}} \mathrm{Cm}^{\mathrm{r}} \mathrm{Km}^{\mathrm{r}}$; suicide vector containing $\mathrm{Tn} 5$ & Simon et al. (1986) \\
\hline pUC19 & $A p^{r} ;$ cloning and expression vector & Yanisch-Perron et al. (1985) \\
\hline pUCP20T & $\mathrm{Ap}^{\mathrm{r}}$; broad-host-range plasmid & Schweizer et al. (1996) \\
\hline pTB3018 & $\begin{array}{l}\text { Cosmid complementing mutants MS1 and MS8; } \mathrm{Tc}^{\mathrm{r}} ; \sim 24 \mathrm{~kb} \\
\text { genomic DNA partially digested with Sau3AI from P. aeruginosa } \\
\text { cloned in Bam HI site of pLAFR } 3\end{array}$ & Schobert \& Görisch (1999) \\
\hline pTB3131 & $\begin{array}{l}\mathrm{Ap}^{\mathrm{r}} \mathrm{Km}^{\mathrm{r}} ; 1 \cdot 0 \mathrm{~kb} \text { PCR product with promoter and } \mathrm{Km}^{\mathrm{r}} \text { gene of } \mathrm{Tn} 5 \\
\text { cloned between EcoRI-BamHI sites of pUC19 }\end{array}$ & This study \\
\hline pTB4100 & $\begin{array}{l}\mathrm{Ap}^{\mathrm{r}} ; 6.9 \mathrm{~kb} \text { HindIII fragment from pTB3018 cloned between HindIII } \\
\text { sites of pUCP20T }\end{array}$ & This study \\
\hline pTB4101 & $\begin{array}{l}\mathrm{Ap}^{\mathrm{r}} ; 2 \cdot 8 \mathrm{~kb} \text { fragment from } \mathrm{pTB} 4100 \text { created by digestion with } S m a \mathrm{I} \\
\text { and religation }\end{array}$ & This study \\
\hline pTB4102 & $\begin{array}{l}\mathrm{Ap}^{\mathrm{r}} ; 4.8 \mathrm{~kb} \text { HindIII-EcoRV fragment from pTB } 4100 \text { cloned between } \\
\text { HindIII-SmaI sites of pUCP20T }\end{array}$ & This study \\
\hline pTB4103 & $\begin{array}{l}\mathrm{Ap}^{\mathrm{r}} ; 2 \cdot 1 \mathrm{~kb} \text { HindIII-EcoRV fragment from pTB } 4100 \text { cloned between } \\
\text { HindIII-SmaI sites of pUCP20T }\end{array}$ & This study \\
\hline pTB4104 & $\begin{array}{l}\mathrm{Ap}^{\mathrm{r}} ; 2 \cdot 8 \mathrm{~kb} \text { fragment from pTB4100 created by digestion with } \\
\text { SalI-EcoRI, filling with Klenow fragment, and religation }\end{array}$ & This study \\
\hline pTB4105 & $\begin{array}{l}\mathrm{Ap}^{\mathrm{r}} ; 2 \cdot 3 \mathrm{~kb} \text { PCR product with complete acs } A \text { gene cloned between } \\
\text { Bam HI sites of pUCP20T (acsA orientation as Plac of pUCP20T) }\end{array}$ & This study \\
\hline pTB4106 & $\begin{array}{l}\mathrm{Ap}^{\mathrm{r}} ; 2 \cdot 3 \mathrm{~kb} \text { PCR product with complete acs A gene cloned between } \\
\text { BamHI sites of pUCP20T (acsA opposite orientation to Plac of } \\
\text { pUCP20T) }\end{array}$ & This study \\
\hline pTB4107 & $\begin{array}{l}\mathrm{Ap}^{\mathrm{r}} \mathrm{Km}^{\mathrm{r}} ; 1 \cdot 0 \mathrm{~kb} S m a \mathrm{I}-S m a \mathrm{I} \text { fragment from pTB3131 containing } \mathrm{Km}^{\mathrm{r}} \\
\text { gene of Tn } 5 \text { cloned in the } S m a \mathrm{I} \text { site of pTB4102 }\end{array}$ & This study \\
\hline pTB4108 & $\begin{array}{l}\mathrm{Ap}^{\mathrm{r}} \mathrm{Km}^{\mathrm{r}} ; 5 \cdot 8 \mathrm{~kb} \text { HindIII-EcoRI fragment from pTB4107 cloned } \\
\text { between HindIII-EcoRI sites of pUC19 }\end{array}$ & This study \\
\hline
\end{tabular}

$* \mathrm{Tc}^{\mathrm{r}}$, tetracycline resistance; $\mathrm{Km}^{\mathrm{r}}$, kanamycin resistance; $\mathrm{Ap}^{\mathrm{r}}$, ampicillin resistance; $\mathrm{Cm}^{\mathrm{r}}$, chloramphenicol resistance.

1997), PROSITE for searching protein sequence motifs (Bairoch et al., 1997), and Pseudomonas genome project version from 2.2.2000 (http://pseudomonas.bit.uq.edu.au/) for obtaining the DNA sequence of the acs $A$ gene.

\section{RESULTS AND DISCUSSION}

\section{Utilization of carbon sources}

Mutants MS1 and MS8 grown in LB broth were inoculated into minimal media containing various carbon sources. In contrast to wild-type cells, ethanol, 2,3butanediol and malonate did not support growth, whilst succinate and glucose supported growth of both wildtype and mutant cells. Acetate supported growth of both mutants; however, the lag phase and the generation time were increased and the final optical density reached was lower when compared to wild-type (Table 2).

\section{Activity of acetate-activating enzymes}

Wild-type $P$. aeruginosa was grown on various carbon sources, while mutants were grown on succinate, glucose or acetate. Cells were collected at lateexponential phase and disrupted. The supernatant after 
Table 2. Growth of $P$. aeruginosa mutants on various substrates

Growth is recorded as final $\mathrm{OD}_{620}$ when reaching stationary phase.,$+++ \mathrm{OD}_{620}=0 \cdot 9-1 \cdot 2 ;++$, $\mathrm{OD}_{620}=0 \cdot 4-0 \cdot 5 ;+, \mathrm{OD}_{620}=0 \cdot 2-0 \cdot 3 ;-$, no growth; $(+)$, as + but indicates a prolonged lag phase compared to the wild-type; ND, not determined. Substrate concentrations as indicated in Methods.

\begin{tabular}{|c|c|c|c|c|c|c|c|}
\hline \multirow[t]{4}{*}{ Substrate } & \multirow[t]{4}{*}{ Wild-type } & \multicolumn{6}{|c|}{ Mutant } \\
\hline & & \multirow[t]{3}{*}{ MS1 } & \multirow[t]{3}{*}{ MS8 } & \multirow[t]{3}{*}{ UK1 } & \multicolumn{3}{|c|}{ Complemented by: } \\
\hline & & & & & \multicolumn{2}{|c|}{ pTB4102 } & \multirow{2}{*}{$\frac{\mathrm{pTB} 4105}{\mathrm{UK} 1}$} \\
\hline & & & & & MS1 & MS8 & \\
\hline Ethanol & +++ & - & - & - & +++ & +++ & +++ \\
\hline 2,3-Butanediol & +++ & - & - & ND & +++ & +++ & ND \\
\hline Malonate & + & - & - & ND & + & + & ND \\
\hline Succinate & +++ & +++ & +++ & +++ & $\mathrm{ND}$ & ND & ND \\
\hline Glucose & +++ & +++ & +++ & ND & ND & ND & ND \\
\hline Acetate & ++ & $(+)$ & $(+)$ & $(+)$ & ++ & ++ & ND \\
\hline
\end{tabular}

Table 3. Enzyme activities in cell-free extracts of wild-type and mutant strains of $P$. aeruginosa grown on or induced by various carbon sources

\begin{tabular}{|c|c|c|c|c|}
\hline \multirow[t]{2}{*}{ Strain } & \multicolumn{2}{|c|}{ Carbon source } & \multicolumn{2}{|c|}{ Specific activity $\left[\mathrm{U}(\mathrm{mg} \text { protein })^{-1}\right]^{*}$} \\
\hline & & & ACS & ACK \\
\hline \multirow[t]{7}{*}{ Wild-type } & Growth: & Ethanol & $0 \cdot 18+$ & $0.53+$ \\
\hline & & 2,3-Butanediol & $0 \cdot 22$ & 0.53 \\
\hline & & Malonate & $0 \cdot 16$ & $0 \cdot 59$ \\
\hline & & Succinate & ND & $0 \cdot 56$ \\
\hline & & Glucose & ND & $0 \cdot 47$ \\
\hline & & Acetate & $0 \cdot 18$ & $0 \cdot 26$ \\
\hline & Induction: & Ethanol & $0 \cdot 28$ & $0 \cdot 60$ \\
\hline \multirow[t]{4}{*}{ MS1 } & Growth: & Succinate & ND & $0 \cdot 52$ \\
\hline & & Glucose & ND & $0 \cdot 40$ \\
\hline & & Acetate & ND & $0 \cdot 48$ \\
\hline & Induction: & Ethanol & ND & $0 \cdot 56$ \\
\hline MS1(pTB4106) & Growth: & Ethanol & $1 \cdot 05 \dagger$ & $0 \cdot 42 \dagger$ \\
\hline \multirow[t]{3}{*}{ UK1 } & Growth: & Succinate & ND & 0.47 \\
\hline & & Acetate & $0 \cdot 018 \ddagger$ & $0 \cdot 26 \neq$ \\
\hline & Induction: & Ethanol & $\mathrm{ND}$ & $0 \cdot 48$ \\
\hline UK1(pTB4105) & Growth: & Ethanol & $0 \cdot 56$ & $0 \cdot 48$ \\
\hline
\end{tabular}

ND, Not detected.

*All values are means of two independent experiments, except where indicated.

†These values are means calculated from three or four independently grown cell batches. Standard deviations of $\pm 13 \%$ for ACS and $\pm 27 \%$ for ACK were calculated.

‡ These activity measurements were performed with a high protein concentration of $6 \mathrm{mg} \mathrm{ml}^{-1}$.

removal of cell debris and the supernatant after removal of membrane fragments by ultracentrifugation at $100000 \boldsymbol{g}$ showed identical activities for ACS and ACK, indicating that the enzymes determined were soluble ones. The acyl-CoA synthesizing activity found with the wild-type after growth on ethanol was almost the same when propionate was used as substrate instead of acetate. However, with butyrate and caproate less than $15 \%$ of activity compared to acetate was found (data not shown). 




Wild-type $P$. aeruginosa expressed both ACS and ACK activity, but no PTA was found under any growth condition used (data not shown). In control experiments with cell-free extracts prepared from E. coli K-12 grown on glucose, PTA activity was easily demonstrated. ACS activity was induced on malonate, 2,3-butanediol, ethanol and acetate, while no activity could be detected on succinate and glucose (Table 3). In contrast, ACK activity is almost independent of the carbon source used.

Like wild-type cells, the mutants exhibited no detectable ACS activity after growth on succinate or glucose. In contrast to the wild-type, mutants also exhibited no detectable ACS activity after growth on acetate under standard test conditions. Mutant activities of ACK are similar to the specific activities of wild-type cells under similar conditions (Table 3).

The activity of ACS was also determined in the wildtype and mutant MS1 after induction on ethanol. Whilst wild-type cells displayed measurable ACS activity, the mutant did not. The ACK activity was the same (Table 3), but no PTA activity was found.

\section{Subcloning and characterization of the acs $A$ gene}

Cosmid pTB3018 from a cosmid gene library of $P$. aeruginosa restored growth on ethanol to mutants MS1 and MS8. Plasmid pTB4100, carrying a $6.9 \mathrm{~kb}$ fragment derived from cosmid pTB3018, also complemented both mutants. Recently, we showed by sequencing a $6.7 \mathrm{~kb}$ fragment carrying the exaABC gene cluster that the DNA sequences of $P$. aeruginosa ATCC 17933 and $P$. aeruginosa PAO1 differ only slightly by about $2 \%$ (Schobert \& Görisch, 1999; Diehl et al., 1998). Therefore, we used the published PAO1 sequence to evaluate the relevant ATCC 17933 sequence. We sequenced $250 \mathrm{bp}$ from the $5^{\prime}$ - and $3^{\prime}$-end of the $6.9 \mathrm{~kb}$ insert of pTB4100. By comparison to the genome database of $P$. aeruginosa PAO1, we identified four ORFs. Further subclones were isolated and tested for complementation by triparental mating. Only pTB4102, with an intact ORF2, complemented both mutants MS1 and MS8 (Fig. 2). Clones carrying only the intact ORF2 were obtained by PCR. In pTB4105, ORF2 is oriented linear with the lac promoter of the vector pUCP20T, whilst in pTB4106, it is integrated in an antilinear orientation. Complementation with both plasmids restored growth on ethanol to mutants MS1 and MS8, indicating that the $P$. aeruginosa promoter of ORF2 is present in the $205 \mathrm{bp}$ region in front of the start codon. We confirmed that the complementation occurred in trans and was not a result of a homologous recombination. Plasmid DNA was prepared from complemented mutant strains and used to transform E. coli JM109. The resulting transformants were used again in triparental matings to complement successfully the original mutants MS1 and MS8.

ORF2 shows high similarity to microbial ACS. The corresponding gene in the genome database of $P$. aeruginosa $\mathrm{PAO} 1$ is designated acs A. A putative ShineDalgarno sequence, GAGG, was found $8 \mathrm{bp}$ upstream of the acs $A$ gene start codon. A putative rho-independent transcription terminator was found $22 \mathrm{bp}$ downstream of the translation stop codon TGA. The inverted repeat with a $10 \mathrm{bp}$ stem was followed by a thymidine-rich sequence. The acs $A$ gene is $1956 \mathrm{bp}$ long and encodes a polypeptide of 652 amino acids. The deduced amino acid sequence revealed no N-terminal signal peptide, indicating that the resulting polypeptide likely is a cytosolic protein. The amino acid sequence shows a high similarity of $82 \%$ to ACS from E. coli (Kumari et al., 1995). Similarities between $68 \%$ and $55 \%$ were found with the respective enzymes of Alcaligenes eutrophus (Priefert \& Steinbüchel, 1992), Saccharomyces cerevisiae (van den Berg \& Steensma, 1995), Neurospora crassa (Connerton et al., 1990), Methanothrix soehngenii (Eggen et al., 1991), Pseudomonas putida (Eaton, 1996) and Bacillus subtilis (Grundy et al., 1993).

Proteins of the ACS family (Wang et al., 1999) share two conserved amino acid sequence regions and both, motif 
I and motif II, are found in the polypeptide sequence encoded by the acs A gene. Motif I represents the AMPbinding site of proteins that catalyse the reaction of ATP and carboxylic acids to acyl adenylates and the transfer of the acyl residue. The function of the conserved motif II is unknown.

\section{Inactivation of the acs $A$ gene}

To demonstrate that the gene product of the acs $A$ gene is essential for growth on ethanol, the gene was inactivated by site-directed mutagenesis using pTB4108 (Fig. 2d). A Km ${ }^{\mathrm{r}}$ mutant, UK1, was obtained as described in Methods. The mutant was unable to grow on ethanol, and PCR with genomic DNA confirmed the presence of the kanamycin-resistance cassette in the acs $A$ gene $\left(\operatorname{acs} A:: \mathrm{Km}^{\mathrm{r}}\right.$ ) (data not shown). The $\mathrm{Km}^{\mathrm{r}}$ gene is transcribed in the same orientation as the acs $A$ gene. The acs $A:: \mathrm{Km}^{\mathrm{r}}$ allele in mutant UK1 does not express a dominant negative variant of ACS, since complementation with pTB4105, carrying only the acs A gene, restored wild-type growth on ethanol and led to a threefold higher expression of ACS activity compared to wild-type cells (Table 2 and Table 3). Like mutants MS1 and MS8, mutant UK1 showed poor growth on acetate (Table 2).

\section{Expression of the acs $A$ gene in complemented mutants MS1, MS8 and UK1}

The acs $A$ gene in $P$. aeruginosa indeed encodes an enzyme with ACS activity as demonstrated by the data shown in Table 3. Wild-type extracts showed ACS activity after induction by ethanol. In contrast, extracts of mutants MS1 and UK1 showed no detectable ACS activity under standard test conditions.

Mutants transformed by triparental mating with plasmid pTB4105 or pTB4106 were grown on ethanol. Cell-free extracts of the complemented mutants showed a three- to five-times higher specific activity of ACS compared to wild-type extracts (Table 3). The acsA gene encodes a polypeptide of $72 \mathrm{kDa}$. With cell-free extracts of induced wild-type cells, a $70 \mathrm{kDa}$ polypeptide band is readily detected by SDS-PAGE, and cell-free extracts from complemented mutants showed an increased intensity of this $70 \mathrm{kDa}$ band (data not shown).

Since mutant UK1, like mutants MS1 and MS8, grows on acetate, albeit poorly, we tried to detect low levels of ACS activity. Cell extract with a high protein concentration was prepared from UK1 cells grown on acetate, and up to $6 \mathrm{mg}$ protein $(\mathrm{ml} \text { assay mixture })^{-1}$ was used. Under these conditions acetyl-CoA formation with a specific activity of about $10 \%$ of wild-type level was detected (Table 3). Apparently this low activity is sufficient to support poor growth of UK1 on acetate. The acetyl-CoA-forming enzyme in mutant UK1, however, showed a different substrate specificity to that observed with ACS in wild-type cells. While ACS in wild-type extracts activated acetate and propionate equally well, the acetyl-CoA-forming activity in UK1 extracts showed about twice the activity with propionate as substrate compared to acetate. With caproate, both, mutant and wild-type extracts, showed only about $15 \%$ of the activity compared to acetate (data not shown).

\section{Concluding remarks}

In the present paper, we demonstrate that the putative acs $A$ gene of $P$. aeruginosa encodes an ACS activity. This enzyme, which so far has not been described in $P$. aeruginosa, is essential for growth on ethanol, 2,3butanediol and malonate. In contrast, mutants with a defect in the acs $A$ gene, however, can still grow on acetate, albeit poorly. By comparison with $P$. aeruginosa PAO1, where the presence of a second putative acs gene, $a c s B$, was inferred from sequence similarities, a second acs gene may also be present in $P$. aeruginosa ATCC 17933. In cell extracts of mutant UK1, where the acs A gene is interrupted by the insertion of a kanamycinresistance cassette, a residual low acetyl-CoA-forming activity was found, which shows a different substrate specificity compared to the wild-type acs $A$ gene product. Whether this activity is caused by an acetyl-CoAforming enzyme encoded by a putative $a c s B$ gene or whether the product of the $\operatorname{acs} A:: \mathrm{Km}^{\mathrm{r}}$ allele shows a residual low activity with an accidentally modified substrate specificity is presently under investigation in our laboratory.

\section{ACKNOWLEDGEMENTS}

This work was supported by the Deutsche Forschungsgemeinschaft.

\section{REFERENCES}

Aceti, D. J. \& Ferry, J. G. (1988). Purification and characterization of acetate kinase from acetate-grown Methanosarcina thermophila. Evidence for regulation of synthesis. J Biol Chem 263, 15444-15448.

Altschul, S. F., Madden, T. L., Schaffer, A. A., Zhang, J., Zhang, Z., Miller, W. \& Lipman, D. J. (1997). Gapped BLAST and PSI-BLAST : a new generation of protein database search programs. Nucleic Acids Res 25, 3389-3402.

Bairoch, A., Bucher, P. \& Hofmann, K. (1997). The PRosite database, its status in 1997. Nucleic Acids Res 25, 217-221.

van den Berg, M. A. \& Steensma, H. Y. (1995). ACS2, a Saccharomyces cerevisiae gene encoding acetyl-coenzyme A synthetase, essential for growth on glucose. Eur J Biochem 231, 704-713.

Berg, P. (1962). Assay and preparation of yeast aceto-CoA-kinase. Methods Enzymol 5, 461-467.

Boyer, H. W. \& Roulland-Dussoix, D. (1969). A complementation analysis of the restriction and modification of DNA in Escherichia coli. J Mol Biol 14, 459-472.

Brown, T. D. K., Jones-Mortimer, M. C. \& Kornberg, H. L. (1977). The enzymic interconversion of acetate and acetyl-coenzyme A in Escherichia coli. J Gen Microbiol 102, 327-336.

Cetin, E. T., Töreci, K. I. \& Ang, Ö. (1965). Encapsulated Pseudomonas aeruginosa (Pseudomonas mucosus) strains. J Bacteriol 89, 1432-1433. 
Champine, J. E. \& Goodwin, S. (1991). Acetate catabolism in the dissimilatory iron-reducing isolate GS-15. J Bacteriol 173, 2704-2706.

Chang, D.-E., Shin, S., Rhee, J.-S. \& Pan, J.-G. (1999). Acetate metabolism in a pta mutant of Escherichia coli W3110: importance of maintaining acetyl coenzyme A flux for growth and survival. J Bacteriol 181, 6656-6663.

Connerton, I. F., Fincham, J. R. S., Sandeman, R. A. \& Hynes, M. J. (1990). Comparison and cross-species expression of the acetyl-CoA synthetase genes of the ascomycete fungi, Aspergillus nidulans and Neurospora crassa. Mol Microbiol 4, 451-460.

Diehl, A., von Wintzingerode, F. \& Görisch, H. (1998). Quinoprotein ethanol dehydrogenase of Pseudomonas aeruginosa is a homodimer. Sequence of the gene and deduced structural properties of the enzyme. Eur J Biochem 257, 409-419.

Eaton, R. W. (1996). P-Cumate catabolic pathway in Pseudomonas putida F1: cloning and characterization of DNA carrying the cmt operon. J Bacteriol 178, 1351-1362.

Eggen, R. I. L., Geerling, A. C. M., Boshoven, A. B. P. \& de Vos, W. M. (1991). Cloning, sequence analysis, and functional expression of the acetyl coenzyme A synthetase gene from Methanothrix soehngenii in Escherichia coli. J Bacteriol 173, 6383-6389.

Figurski, D. H. \& Helinski, D. R. (1979). Replication of an origincontaining derivative of plasmid RK2 dependent on a plasmid function provided in trans. Proc Natl Acad Sci USA 76, 1648-1652.

Groves, W. E., Davis, F. C. \& Sells, B. H. (1968). Spectrophotometric determination of microgram quantities of protein without nucleic acid interference. Anal Biochem 22, 195-210.

Grundy, F. J., Waters, D. A., Takova, T. Y. \& Henkin, T. M. (1993). Identification of genes involved in utilization of acetate and acetoin in Bacillus subtilis. Mol Microbiol 10, 259-271.

Hanahan, D. (1983). Studies on transformation of Escherichia coli with plasmids. J Mol Biol 166, 557-580.

Jetten, M. S. M., Stams, A. J. M. \& Zehnder, A. J. B. (1989). Isolation and characterization of acetyl-coenzyme A synthetase from Methanothrix soehngenii. J Bacteriol 171, 5430-5435.

Jones, M. E. \& Lipmann, F. (1955). Aceto-CoA-kinase. Methods Enzymol 1, 585-590.

Kumari, S., Tishel, R., Eisenbach, M. \& Wolfe, A. J. (1995). Cloning, characterization, and functional expression of acs, the gene which encodes acetyl coenzyme A synthetase in Escherichia coli. J Bacteriol 177, 2878-2886.

Oberlies, G., Fuchs, G. \& Thauer, R. K. (1980). Acetate thiokinase and the assimilation of acetate in Methanobacterium thermoautotrophicum. Arch Microbiol 128, 248-252.

Powlowski, J., Sahlman, L. \& Shingler, V. (1993). Purification and properties of the physically associated meta-cleavage pathway enzymes 4-hydroxy-2-ketovalerate aldolase and aldehyde dehydrogenase (acylating) from Pseudomonas sp. strain CF600. J Bacteriol 175, 377-385.
Priefert, H. \& Steinbüchel, A. (1992). Identification and molecular characterization of the acetyl coenzyme A synthetase gene $(a c o E)$ of Alcaligenes eutrophus. J Bacteriol 174, 6590-6599.

Reichmann, P. \& Görisch, H. (1993). Cytochrome $c_{550}$ from Pseudomonas aeruginosa. Biochem J 289, 173-178.

Rupp, M. \& Görisch, H. (1988). Purification, crystallization and characterization of quinoprotein ethanol dehydrogenase from Pseudomonas aeruginosa. Biol Chem Hoppe-Seyler 369, 431-439.

Sambrook, J., Fritsch, E. F. \& Maniatis, T. (1989). Molecular Cloning: a Laboratory Manual, 2nd edn. Cold Spring Harbor, NY : Cold Spring Harbor Laboratory.

Schobert, M. \& Görisch, H. (1999). Cytochrome $c_{550}$ is an essential component of the quinoprotein ethanol oxidation system in Pseudomonas aeruginosa: cloning and sequencing of the genes encoding cytochrome $c_{550}$ and an adjacent acetaldehyde dehydrogenase. Microbiology 145, 471-481.

Schweizer, H. P., Klassen, T. R. \& Hoang, T. (1996). Improved methods for gene analysis in Pseudomonas. In Molecular Biology of Pseudomonads, pp. 229-237. Edited by T. Nakazawa, K. Furukawa, D. Haas \& S. Silver. Washington, DC: American Society for Microbiology.

Simon, R., O'Connell, M., Labes, M. \& Pühler, A. (1986). Plasmid vectors for the genetic analysis and manipulation of rhizobia and other gram-negative bacteria. Methods Enzymol 118, 640-659.

Smith, A. W. \& Iglewski, B. H. (1989). Transformation of Pseudomonas aeruginosa by electroporation. Nucleic Acids Res 17, 10509.

Staskawicz, B., Dahlbeck, D., Keen, N. \& Napoli, C. (1987). Molecular characterization of cloned avirulence genes from race 0 to race 1 of Pseudomonas syringae pv. glycinea. J Bacteriol 169, 5789-5794.

Steinbüchel, A., Fründ, C., Jendrossek, D. \& Schlegel, H. G. (1987). Isolation of mutants of Alcaligenes eutrophus unable to derepress the fermentative alcohol dehydrogenase. Arch Microbiol 148, 178-186.

Taylor, I. J. \& Anthony, C. (1976). Acetyl-CoA production and utilization during growth of the facultative methylotroph Pseudomonas AM1 on ethanol, malonate and 3-hydroxybutyrate. J Gen Microbiol 95, 134-143.

Thompson, D. K. \& Chen, J. S. (1990). Purification and properties of an acetoacetyl coenzyme A-reacting phosphotransbutyrylase from Clostridium beijerinckii. Appl Environ Microbiol 56, 607-613.

Wang, S., Nakashima, S., Numata, O., Fujiu, K. \& Nozawa, Y. (1999). Molecular cloning and cell-cycle-dependent expression of the acetyl-CoA synthetase gene in Tetrabymena cells. Biochem J 343, 479-485.

Yanisch-Perron, C., Vieira, J. \& Messing, J. (1985). Improved M13 phage cloning vectors and host strains: nucleotide sequence of the M13mp18 and pUC19 vectors. Gene 33, 103-119.

Received 4 June 2001; accepted 18 June 2001. 